\title{
VI. Experiments and observations on certain stony and metalline substances which at different times are said to have fallen on the earth; also on various kinds of native iron
}

\section{Edward Howard Esq. F.R.S.}

To cite this article: Edward Howard Esq. F.R.S. (1802) VI. Experiments and observations on certain stony and metalline substances which at different times are said to have fallen on the earth; also on various kinds of native iron, Philosophical Magazine Series 1, 13:49, 23-31, DOI: 10.1080/14786440208676085

To link to this article: http://dx.doi.org/10.1080/14786440208676085

$$
\text { 曲 Published online: } 18 \text { May } 2009 .
$$

Submit your article to this journal ¿

\section{山ll Article views: 2}

Q View related articles ¿ 
* * Repeated experiments of the above invention were made by the committee; from the refult of which it appeared to poffefs fome advantages over the common wheel, and to have a greater power of action.

Defcription of the late Mr. Befant's Water-wbeel. (Plate I. fig. 2 and 3 )

A, (fig. 2.) the body of the water-wheel, which is hollow in the form of a drum, and is fo conftructed as to be proof againft the admiffion of water within it.

$B$, the axis on which it turns.

$\mathrm{C}$, the float - boards, placed on the periphery of the wheel. Each board is obliquely fixed firm to the rim of it, and to the body of the drum.

$D$, the refervoir, containing the water.

$E$, the penftock, which regulates the quantity of water running to the wheel.

$F$, the current of water which has paffed the wheel.

Fig. 3 is a front view of the water-wheel, fhowing the oblique direction in which the float-boards, C, are placed on the face of the wheel.

VI. Experiments and Obfervations on certain Stony and Metalline Subftances wbicb at different Times are faid to bave fallen on the Eartb; aljo on various Kinds of Native Iron. By EDWand HowaRD, Efq. F.R.S.*

$\mathrm{T}$

$\mathrm{HE}$ concordance of a variety of facts feems to render it moft indifputable, that certain ftony and metalline fubftances have, at different periods, fallen on the earth. Whence their origin, or whence they came, is yet, in my judgment, involved in complete obfeurity.

The accounts of thefe peculiar fubftances, in the early annals, even of the Royal Society, have unfortunately been blended with relations which we now confider as fabulous; and the more antient hiftories of ftones fallen from heaven, from Jupiter, or from the clouds, have evidently confounded fuch fubftances with what have been ternied icraunia, botilia, ombria, brontia, \&c. names altogether unappropriate to fubftances fallen on our globe. Indeed fome minead, and others are inexpreffive.

The term ieraunia, by a mifnomer, deduced from its fuppoled origin, feems, as well as boctiliat, to have been an-

* From the TranfuRtions of the Rojal Societr of london for 1 Soz.

+ Mercati, Metällotheca Vaticana, p. 241. 
tiently ufed to denute many fpecies of ftones, which were polithed and thaped into various forms, though moftly wedgelike or triangular, fometimes as inftruments, fometimes as oracles, and lometimes as deities. The import of the names ombria, brontia, \&c. feems fubject to the fame uncertainty.

In very early ages it was believed that ftones did in reality fall, as it was faid, from heaven, or from the gods; thefe, either from ignorance, or perhaps from fuperftitious views, were confounded with other ftones, which, by their compact aggregation, were better calculated to be thaped into different inftruments, and to which it was convenient to attach a fpecies of myfterious veneration. In modern days, becaufe explofion and report have generally accompanied the defcent of fuch fubftances, the name of thunderbolt, or thunderftone, has ignorantly attached itfelf to them; and becaufe a variety of fubftances accidentally prefent near buildings and trees ftruck with lightning have, with the fame ignorance, been collected as thunderbolts, the thunderbolt and the fallen metalline fubftance have been ranked in the fame clafs of abfurdity. Certainly, fince the phænomena of lightning and electricity have been fo well identified, the idea of a thunderbolt is ridiculous. But the exiftence of peculiar fubftances fallen on the earth, I cannot hefitate to affert; and on the concordance of remote and authenticated facts I fhall reft the affertion.

Mr. King, the learned author of " Remarks concerning Stones faid to have fallen from the Clouds, in thefe Days, and in antient Times," has adduced quotations of the greateft antiquity, defcriptive of the defocnt of fallen ftones; and, could it be thought neceffary to add antique teftimonies to thofe inftanced by fo profound an antiquarian, the quotations of Monf. Falconet, in his papers upon boetilia, inferted in the Hifloire des Infcriptions at Belles-Lettres* ; the quotations in Zahn's Specula Pbyfico-natbematica Hiftorianat: the Filica Sotterranea of Giacinto Gemma ; the worts of lliny, and others, night be referred to.

Dr. Chladni, in his "Obfervations on the Mafs of Iron found in Siberia, and on other Mafies of the like Kind," as well as in his "Obfervations on Fire-balls and hard Bodies fullen from the Atmofphere," has collected almolt every modern inftance of phenomena of this nature.

Mr. Sonthey relatcs an account, juridically anthenticated, of a fone weighing ton pounds which was heard to fall in

r Tom. vi. pa;19, et tom. xyiii. p. 228.

+ Fol. 1696 , vol. i. p. $3^{8} ;$, where a long cuumeration of ftones fallen from the $k y$ is given.

Portugal 
Portugal Feb. 19, 1796, and was taken, ftill warm, from the ground :

The firt of thefe peculiar fubftances with which chemiftry has interfered, was the ftone prefented by the abbe Bachelay to the Royal French Academy. It was found on the $13^{\text {th }}$ of Sept. 1768 , yet hot, by perfons who faw it fall. It is deferibed as follows $\uparrow$ :

"The fubitance of this ftone is of a pale afh-gray colour; when examined with a magnifying glafs, it is found to be interfperfed with a multitude of fmall brilliant metallic points of a pale yellow colour; its exterior furface, that which, according to the abbé Bachelay, was not engaged in the earth, was covered with a fmall and very thin ftratum of a blackifh matter, putfed up in fome places, and which appeared to have been fufed. This ftone, when the interior of it was ftruck with fteel, produced no fparks : on the other hand, when ftruck on the thin external ftratum, which appeared to have been attacked by fire, fome few fparks were elicited."

The fpecific gravity of this ftone was as 3535 to 1000 . The academicians analyfed the ftone, and found it to contain

$$
\begin{array}{lll}
\text { Sulphur - } & - & 8 \frac{1}{2} \\
\text { Iron }- & - & 36 \\
\text { Vitrifiable earth } & - & \frac{55^{\frac{\pi}{2}}}{100}
\end{array}
$$

Of their mode of analyfis, I thall have occafion to fpeak hereafter. They were induced to conclude, that the ftone, prefented to the arademy by the abbe Bachelay, did not owe its origin to thunder; that it did not fall from heaven; that it was not formed by mineral fubftances, fufed by lightning; and that it was nothing but a fpecies of pyrites, without peculiarity, except as to the hepatic frnell difengaged from it by marine acid. "That this ftone, which was, perhaps, covered bv a fmall ftratum of earth or turf, may have been ftruck with lightning, and thus uncovered: the heat may have been fulficiently great to fufe the furface of the part ftruck, but it may not have been long enough continued to be able to penetrate to the infide: on this account, the ftone has not been decompofed. The quantity of metallic matters it contains, oppofing lefs refiftance than another body to the current of the electric mutter, may perhaps have contributed to determine the direction of the lightning."

The memoir is however concluded, by obferving it to be

* Letters written during a Thort Refidence in Spain and Portugal, page 239 .

+ Here, and in the two following quotations, Mr. Howard gives the original words of the author: we have fubfitured faithful tranflations.EUIT.

fufficiently 
fufficiently fingular, that M. Morand le fils had prefented a fragment of a ftone, from the environs of Coutances, alfo faid to have fallen from heaven, which only differed from that of the abbé Bachelay becaufe it did not exhale the hepatic fmell with fpirit of falt. Yet the academicians did not think any conclufion could be drawn from this refemblance, unlefs that the lightning had fallen by preference on pyritical matter *.

Monf. Barthold, profeffeur à l'école centrale du HautRhim, gave, I believe, the next, and laft $t$, analytical account of what he alfo denominates pierre de tonnerre. He defcribes it thus:- " The mafs of ftone known under the name of fierre de tonnerre d'Enffbeim, weighing about two quintals, has its exterior form rounded, almoit oval, is rugged, and of a dull earthy appearance.

"The ground of the ftone is of a blueifh gray colour interfperfed with infulated cryftals of pyrites, the cryftallization of which is confufed, in fome places fcaly, accumulated, forming nodes and fmall veins, which traverfe it in every direction: the pyrites is of a golden colour: polifhing gives it the fplendour of fteel, and, when expofed to the atmolphere, it becomes tarnifhed and brown. One may diftinguifh alfo with the naked eye gray fcaly iron ore, not fulphureous. fufceptible of being attracted by the magnet, little oxidated, or approaching much to the metallic ftate.

"C The fracture is irregular, granulated, of a grain fomewhat compact: in the inficle very fmall fifures are feen. It does not ftrike fire with ftecl: its texture is fo foft, that it readily fuffers itfelf to be attacked by a knife. By pounding, it is eafily reduced to a blueifh gray powder of an earthy ondour. Sometimes there are found fmall cryttals of iron ore, which prefent a greater refiftance to the blows of the ftamper."

The fpecific gravity of the piece in profeffor Barthold's poffeffion was 3233 , difilled water being taken at 1000 .

The analyfis of $M$. Barthold, of which I thall alfo have eccafion to. Speak bereafter, gave in the 100,

\begin{tabular}{lllr} 
Sulphur & - & - & 2 \\
Iron & - & - & 20 \\
Magnefia & - & - & 14 \\
Alumina & - & - & 17 \\
Lime & - & - & 2 \\
Silica & - & - & 42 \\
\hline
\end{tabular}

- Sce Formal de Fh:fique, tom. ii. p. $25 \mathrm{r}$.

1. A very interctfing deral of a metcor, and of ftones fallen in July 790, was given by proteffeur Baudin in the thagazin fur das Niufte aus dur poysk, by profe?tur Voigt.

From 
From the extcrnal characters, and from his analyfis, the proteffor confiders the ftone of Enfifheim to be argillo-ferruginous; and is of opinion, that ignorance and fuperftition have attributed to it a miraculous exiftence, at variance with the firft notions of natural philofophy *

The account next in fucceffion is already printed in the Tranfactions of the Royal Society ; but cannot be omitted, as it immediately relates to one of the fubitances I bave examined. I allude to the letter received by $\mathrm{Sir}$ William $\mathrm{Ha}$ milton from the earl of Briftol, dated from Sienna, July 12, 1794:- " In the midft of a moft violent thunder-ftorm, about a dozen ftones, of various weights and dimenfions, fell at the feet of different perfons, men, women, and children. The ftones are of a quality not found in any part of the Siennefe territory: they fell about eighteen hours after the enormous eruption of mount Vefuvius; which circumftance leaves a choice of difficulties in the folution of this extraordinary phrenomenon. Lither thefe ftones have been generated in this igneous mafs of clouds, which produced fuch unufual thunder; or, which is equally incredible, they were thrown from Vefuvius, at a diftance of at leaft 250 miles; judge then of its parabola. The philofophers here incline to the firft folution. I wilh much, Sir, to know your fentiments. My firt objection was to the fact itfelf; but of this there are fo many eye witneffes, it feems impoflible to withftand their evidence." (Phil. Trauf. for 1795, p. 103.) Sir William Hamilton, it feems, alfo received a piece of one of the larget ftones, which weighed upwards of five pounds; and had feen another which weighed about one. He likewife obferved, that the outfide of every ftone which had been found, and had been afcertained to have fallen from the clouds near Sienna, was evidently frefhly vitrified, and was black, having every fign of having paffed through an extreme heat; the intide was of a light gray colour, mixed with black fpots and fome flining particles, which the learned there had decided to be pyrites.

In 1796 a ftone weighing 56 pounds was exhibited in London, with feveral atteftations of perfons who, on the $13^{\text {th }}$ of December 1795, faw it fall, near Wold Cottage, in Yorkfhire, at about three o'clock in the afternoon. It had penetrated through twelve inches of foil and fix inches of folid chalk rock; and, in burying itfelf, had thrown up an immenfe quantity of earth to a great diftance: as it fell, a number of explofions were heard, about as loud as piftols.

* Sce journal de Pbyique, Ventufe, an. 8, p. 169. 
In the adjacent villages, the founds heard were taken for guns at fea; but, at two adjoining villages, were fo diftinct of fomething fingular paffing through the air, towards the habitation of $\mathrm{Mr}$. Topham, that five or fix people came up to fee if any thing extraordinary had happened to his houfe or grounds. When the itone was extracted, it was warm, fmoked, and fmelt very firong of fulphur. Its courfe, as far as could be collected from different accounts, was from the fouth-weft. The day was mild and hazy, a fort of weather very frequent in the Wold hills, when there are no winds or ftorms; but there was not any thunder or lightning the whole day. No fuch fone is known in the country. There was no eruption in the earth; and, from its form, it could not come from any building; and, as the day was not tempeftuous, it did not feem probable that it conld have been forced from any rocks, the neareft of which are thofe of Flamborough Head, at a diftance of twelve miles*. The neareft volcano I believe to be Hecla in Iceland.

The exhibition of this ftone as a fort of fhow, did not tend to accredit the account of its defcent, delivered in a handbill at the place of exhibition; much lefs could it contribute to remove the objections made to the fall of the fones prefented to the Royal French Academy. But the right hon. Prefident of the Royal Society, ever alive to the intereft and promotion of fcience, obferving the ftone fo exhibited to refemble a ftrne fent to him as one of thofe fallen at Sienna, could not be minled by prejudice : he obtained a piece of this extraordinary mafs, and collected many references to defcriptions of fimilar phenomena. At length, in 1799, an account of ftones fallen in the Eaft Indies was fent to the prefident by John Lloyd Williams, efq. which, by its unqueftionable authenticity, and by the ftriking refemblance it bears to other accounts of fallen ftones, muft remove all prejudice. Mr. Williams has fnce drawn up the following more detailed narrative of facts.

Account of the Explofion of a Mateor near Benares, in the Eaft Indics; and of the Futling of fome Stones at the fame Time, about 14 Miles from that Caty. By John Lloyd Williams, F/q. F. i. S.

A circumftance of to crtraordinary a nature as the fall of ftones from the heavens could not fail to excite the wonder and attract the attention of every inquifitive mind.

Among a fupertitions porple, any preternatural appearance is viewer whin fient awo and reverence: attributing the

* Extracted from the printed paper delivered at the place of exhibition. caures 
caufes to the will of the Supreme Being, they do not prefume to judge the means by which they were produced, nor the purpofes for which they were ordered; and we are naturally led to fufpect the influence of prejudice and fuperftition in their defcriptions of fich phænomena: my inquiries were therefore chiefly directed to the Europeans, who were but thinly difperfed about that part of the country.

The information I obtained was, that on the I gth $^{\text {th }}$ December 1798 , about eight o'clock in the evening, a very luminous meteor was obferved in the heavens, by the inhabitants of Benares and the parts adjacent, in the form of a large ball of fire; that it was accompanied by a loud noife refembling thunder; and that a number of ftones were faid to have fallen from it near Krakhut, a village on the north fide of the river Goomty, about 14 miles from the city of Benares.

The meteor appeared in the weftern part of the hemifphere, and was but a fhort time vifible: it was obferved by feveral Europeans, as well as natives, in different parts of the country.

In the neighbourhood of Jnanpoor, about twelve miles from the fpot where the ftones are faid to have fallen, it was very diftinctly obferved by feveral European gentlemen and ladies; who defcribed it as a large ball of fire, accompanied with a loud rumbling noife, not unlike an ill-difcharged platom of mufketry. It was alfo feen, and the noife heard, by various perfons at Benares. Mr. Davis obferved the light come into the room where he was, through a glafs window, fo ftrongly as to project hadows from the bars between the panes, on a dark coloured carpet, very diftinctly ; and it appeared to him as luminous as the brighteft moonlight.

When an account of the fall of the ftones reached Benares, Mr. Davis, the judge and magiftrate of the diftrict, fent an intelligent perfon to make inquiry on the fpot. When the perfon arrived at the village near which the ftones were faid to have fallen, the natives, in anfwer to his inquiries, told him, that they had either broken to pieces, or given away to the tefeldar (native collestor) and others, all that they had picked up; but that he might eafily find fome in the adjacent fields, where they would be readily difcovered (the crops being then not above two or three inches above the ground) by obferving where the earth appeared recently turned up. Following thefe directions, he found four, which he brought to Mr. Davis : moft of thefe the force of the fall had buried, according to a meafure he produced, about fix inches deep, in fielus which fermed to have been recently watered; and 
it appeared, from the man's defcription, that they muft have lain at the diftance of about a hundred yards from each other.

What he further learnt from the inhabitants of the village concerning the phænomenon was, that about eight o'clock in the evening, when retired to their babitations, they obferved a very bright light, proceeding as from the $\mathrm{ky}$, accompanied with a loud clap of thunder, which was immediately followed by the noifc of heary bodies failing in the vicinity. Uncertain whether fome of their deities might not have been concerned in this occurrence, they did not venture out to inquire into it until the next moruing; when the firft circumftance which attracted their attention was the appearance of the earth being turned up in different parts of their fields as before mentioned, where, on examining, they found the ftones.

The affifant to the collector of the diftrigt, Mr. Erfkine, a very intelligent young gentleman, on feeing one of the ftones, brought to him by the native fuperintendant of the collections, was alfo induced to fend a perfon to that part of the country to make inquiry; who returned with feveral of the ftones, and brought an account fimilar to that given by the perfon lent by Mr. Davis, together with a confirmation of it from the cauzy, (who had been directed to make the inquiry,) under his hand and feal.

Mr. Maclane, a gentleman who refided verv near the village of Krakhut, gave me part of a ftone that had been brought to him the moming after the appearance of the phrenomenon, by the watchman who was on duty at his houfe; this, be faid, had fallen through the top of his but, which was clofe by, and buried itfelf feveral inches in the floor, which was of confolidated earth. The ftone mutt, by his account, previous to its having been broken, have weighed upwards of two pounds.

At the time the meteor appeared, the $\mathrm{ky}$ was perfectly ferene; not the fmalleft veftige of a cloud had been feen fince the 1 Ith of the month, nor were any obferved for many days after.

Of thefe ftones, I bave feen eight, nearly perfeet, befides parts of feveral others, which had been broken by the potfeflors to diftribute among their friends. The form of the more perfect ones appeared to be that of an irregular cube, rounded off at the edges; but the angles were to be obferved on moit of them. They were of various fizes, from about three to upwards of four inches in their iargeft diameter; one of them, meafuring four inches and a quarter, weighed two pounds twelve ounces. In appearance, they were ex- 
afly fimilar : externally they were covered with a hard black coat or incruftation, which in fome parts had the appearance of varnifh, or bitumen; and on moft of them were fractures, which, from their being covered with a matter fimilar to that of the coat, feemed to have been made in the fall, by the ftones ftriking againft each other, and to have paffed through fome medium, probably an intenfe heat, previous to their reaching the earth. Internally, they confifted of a number of fmall fpherical bodies, of a llate colour, embedded in a whitilh gritty fubttance, interfperfed with bright thining fpicula, of a metallic or pyritical nature. The fpherical bodies were much harder than the reft of the ftone: the white gritty part readily crumbled, on being rubbed with a hard body; and, on being broken, a quantity of it attached itfelf to the magnet, but more particularly the outfide coat or cruft, which appeared almoft wholly attractable by it.

As two of the more perfect ftones which I had obtained, as well as parts of fome others, have been examined by feveral gentlemen well verfed in mineralogy and chemiftry, I thall not attempt any further defcription of their conftituent parts; nor thall I offer any conjecture refpecting the formation of fuch fingular productions, or even record thofe which I have heard of others, but leave the world to draw their own inferences from the facts above related. I thall only obferve, that it is well known there are no volcanos on the continent of India; and, as far as I can learn, no ftones have been met with in the earth, in that part of the world, which bear the fmalleft refemblance to thofe above defcribed.

[To be continued.]

VII. Mineralogical Notice refpecting two great Peculiaritics lately found in Iron-fone from Huchenburg and Ijibenburg. By Mr. Cr a M ER, Counjellor of Mines at Altenkircben*.

$\mathrm{T}$

HE firf mineral I thall here mention is native iron. It is well known that a difpute has long exifted among mineralogifts refpecting the actual exifience of this fubftance; that by fome it bas always been donbted; and that, befides the monftrous mafs of which profeffor Pallas has given a circumttantial defcription, few fpecimens have ever been producid to give fupport to the affertion, that this mineral is found in a natural ftate. The certainty of its exiltence has

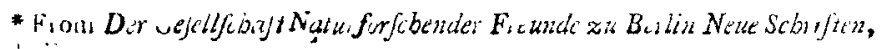
vol. ii. 